Vorbemerkung ...................... 9

Dank ........................... 11

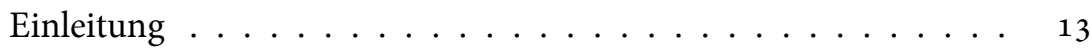

Eine Vorrede $[\mathrm{zu}$ Reden über das Judentum $]$. . . . . . . . . . 27

Der wahre Lehrer . . . . . . . . . . . . . . . . 33

Im Anfang . . . . . . . . . . . . . . 34

Nachahmung Gottes . . . . . . . . . . . . 35

Vertrauen ........................ 45

[Achad Haam-Gedenkfeier in Berlin] . . . . . . . . . . 46

Klärung . . . . . . . . . . . . . . . . . . . 49

[Rede auf dem XV. Zionisten-Kongreß] . . . . . . . . . . 50

[Brief an Melchior Britschgi-Schimmer] . . . . . . . . 57

Das hebräische Buch . . . . . . . . . . . . . . . 59

Lebensfrömmigkeit . . . . . . . . . . . . 60 60

Der Glaube des Judentums . . . . . . . . . . . . . . . . 63

Drei Stationen . . . . . . . . . . . . . . . . . 75

Für die Sache der Treue $\ldots \ldots \ldots \ldots$. . . . . . . 76

Franz Rosenzweig $\dagger \ldots \ldots$. . . . . . . . . . . . . 79

Das Judentum und die neue Weltfrage . . . . . . . . . 85

Vorrede $[$ zu Kampf um Israel $] \ldots \ldots$

Das Erste $\ldots \ldots \ldots \ldots \ldots \ldots$

Ein Dankesgruss . . . . . . . . . . . . . . . 96

Der jüdische Mensch von heute . . . . . . . . . . . . . 97

Adel . . . . . . . . . . . . . . . . . 98 
Gericht und Erneuerung . . . . . . . . . . . . . . . . . 99

Name verpflichtet . . . . . . . . . . . . . . . . . . 101

Vorbehaltlose Hingabe: Der Weg ． . . . . . . . . . . 102

Freiheit und Aufgabe . . . . . . . . . . . . . . 103

Ein Spruch des Maimuni . . . . . . . . . . . . . . . 107

Martin Buber schreibt uns: . . . . . . . . . . . . . . . . . 109

Vorbemerkung [zu Hermann Cohen, Der Nächste] . . . . . . 110

Vorwort $[\mathrm{zu}$ Die Stunde und die Erkenntnis $]$. . . . . . . . . . 111

Der Jude in der Welt . . . . . . . . . . . . . . . . 113

Die Lehre und die Tat . . . . . . . . . . . . . . . 117

Offenbarung und Gesetz . . . . . . . . . . . . . . . . 126

Israel und die Völker . . . . . . . . . . . . . . . 131

Ein Wort an Dreizehnjährige . . . . . . . . . . . . . . . . 144

Hebräischer Humanismus ．. . . . . . . . . . . . . . 147

Religion in unserem Land . . . . . . . . . . . . . . 159

In Theresienstadt ... . . . . . . . . . . . . . . . 167

Treue zum Geist . . . . . . . . . . . . . . . . . . . . . 168

Preface $[\mathrm{zu}$ Israel and the World $] \ldots \ldots$

Israel und Palästina . . . . . . . . . . . . . . . . . 171

Vorwort . . . . . . . . . . . . . . . . 172

Einleitung: Zion und die nationalen Ideen $\ldots \ldots \ldots$

Erster Teil: Biblisches Zeugnis . . . . . . . . . . . . . . . 178

Zweiter Teil: Deutung und Verklärung _. . . . . . . . 208

Dritter Teil: Die Stimme des Exils . . . . . . . . . . . . . . 225

Vierter Teil: Der zionistische Gedanke . . . . . . . . . . 268

Biographisches . . . . . . . . . . . . . 315

Einige Worterklärungen $\ldots \ldots \ldots \ldots 316$

Thoughts on the Jewish New Year . . . . . . . . . . . . 317

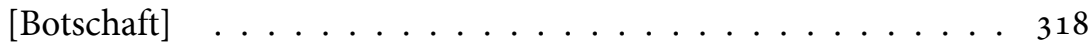


An der Wende . . . . . . . . . . . . . . . . . . . . . . . 319

Vorwort . . . . . . . . . . . . . . 320

Die erste Rede: Der Geist Israels und die Welt von heute . . . . . . 321

Die zweite Rede: Judentum und Kultur . . . . . . . . . . . . 329

Die dritte Rede: Die heimliche Frage ～. . . . . . . . . . . 337

Die vierte Rede: Der Dialog zwischen Himmel und Erde . . . . . . 345 »Er macht Frieden" . . . . . . . . . . . . . . . . . 354

Greetings to Dr. Mordecai M. Kaplan . . . . . . . . . . . . 355

»Fuer das Ganze zeugend" . . . . . . . . . . . . . . . . . . . . 357

Gershom Scholem - 6o Jahre alt . . . . . . . . . . . . . 358

Funktion des Geistes in der Geschichte . . . . . . . . . . . 359

Über die Ewigkeit und den Augenblick . . . . . . . . . . . 360

\section{Unveröffentlichte Archivmaterialien}

Der Glaube an die Wiedergeburt $\ldots \ldots \ldots 66$ Mein Liberalismus . . . . . . . . . . . . . . . . 382

\section{Kommentar}

Editorische Notiz . . . . . . . . . . . . . . . . 386

Diakritische Zeichen $\ldots \ldots \ldots \ldots \ldots$

Einzelkommentare . . . . . . . . . . . . . . . . 389

Abkürzungsverzeichnis . . . . . . . . . . . . . . . 617

Quellen- und Literaturverzeichnis . . . . . . . . . . . . . .621

Glossar . . . . . . . . . . . . . . . . . 6632

Stellenregister . . . . . . . . . . . . . . 6 635

Sachregister . . . . . . . . . . . . . . . . 640

Personenregister . . . . . . . . . . . . . . . 646

Gesamtaufriss der Edition . . . . . . . . . . . . . 659 
